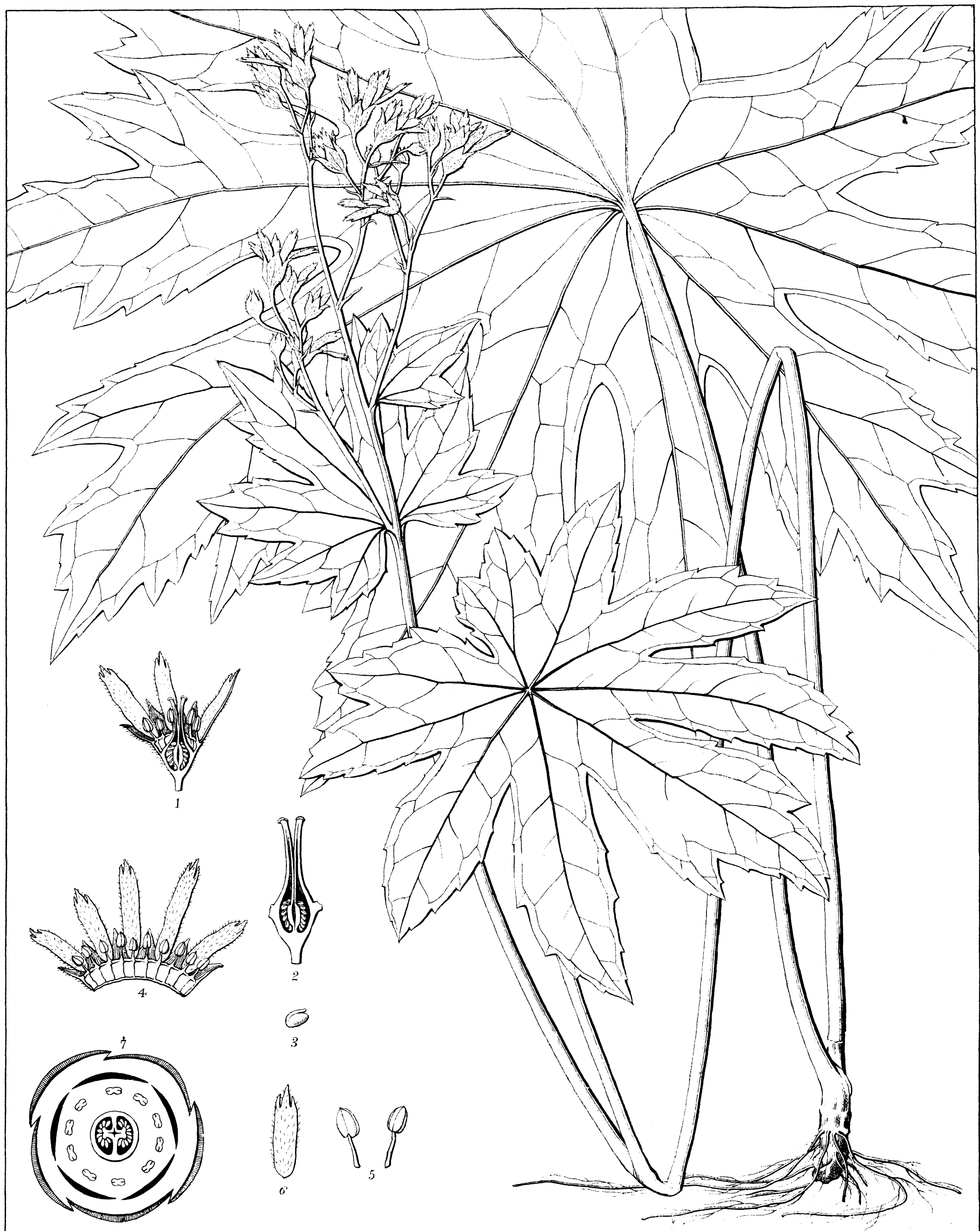




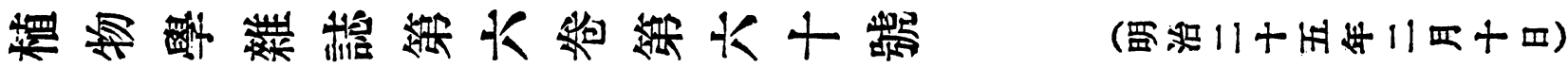

THE BOTANICAL MAGAZINE.

[Vol. VI .

February 10, 1892.

No.60.]

\section{New or Little Known Plants of Japan.}

No. 18.

Ryōkichi Yatabe, Sc. D.

Saxifraga Watanabei, nov. sp.

Nom. jap. Watanabesō. ワヌナベサウ.

Saxifrageze.

(Plate II.)

站

I

Rhizome short. Stem robust, smooth or very slightly hairy, 2-3-leaved, 2 feet or more high. Radical $+$

粈 leaves long-petioled, smooth, peltate, orbicular, pale on the under surface, palmately 8-10-ribbed, cut into 8-10 subcuneate lobes, about Io inches in diameter; lobes 2-3-lobulate, the lobules acuminate and coarsely and unequally toothed; petioles sheathing at the base, more than a foot long. The lowest stem-leaf like the radical, but smaller; the upper short-petioled or sessile, small, few-lobed, passing into lanceolate or linear-lanceolate bracts. Cymes several-flowered, axillary and terminal, lower ones with peduncles of 2-3 inches, upper ones with much shorter peduncles; pedicers I-3 lincs long; bracteoles linear-lanceolate, acuminate, $\mathrm{I}-3$ lines long. Caly $\mathbf{x}-\mathrm{tube}$

New or Little Known Plants of Japan. 
subcampanulate, Io-nerved glandular-hairy, adnate to the ovary at the base, 3 lines long and broad; its limb 5lobed; the lobos deltoid, acute, glandular-hairy, 2-lines long, I line broad. Petals 5, inserted on the calyx-tube at the base of its lobes, unequal, linear, 2-3-toothed at the apex, glandular-hairy, slightly yellowish, 4-5 lines long, about I line broad. Stamens Io, inserted with the petals on the calyx-tube, those alternate with the petals somewhat longer than the rest; filaments subulate, about I line long; anthers basifixed, 2-celled, ovate, acutish at the apex, cordate at the base, somewhat shorter than the filaments. Ovary semi-inferior, 2-celled, 2-lobed at the apex; styles 2, I $\frac{1}{2}$ lines long; stigma capitate; seeds numerous, anatropous, attached to axile placentæ.-Hab. moist woods in mountain. Fl. July.

Specimens of this plant were collected by $\mathrm{Mr}$, Kanō Watanabe at Nanokawa-mura in the province of Tosa, on the 12th. of July, 1889.

This species is nearly related to Saxifraga tellimoides, Maxim. (Mél Biol, vol. vii., pp. 6 et 603 .), but can be at once distinguished by the character of the leaves and petals. The leaves of the latter are somewhat hairy and not so deeply lobed as those of the former, and the petals of the latter are decidedlly spathulate.

Plate II. Fig. I, flower cut vertically; 2, vertical section of pistil; 3, ovule; 4, free portion of calyx laid open 
with petals and staments; 5 . dorsal and ventral views of stamens; 6 , petal; 7, floral diagram:-all enlarged.

\section{Notes on Japanese Plants, XV. \\ 日本植物報知 第十五. \\ Tomitaro Makino.}

Descriptions of the new species and varieties in the following list will be given in the next number.

\section{FILICES. しで程}

Trichomanes acuta sp. nov. Jap. Kokehoragoke. コケホシゴケ TOSA: Shiraishi, Nanokawa (T. Makino).

Lomaria castanea sp. nov. Jap. Miyamashishigashira. ミャマシ・ガンフ KōDuKE: Shishimidutōge (T. Makino). Rıkuchū: Mt. Kurikoma (T. Makino).

Asplenium Miyoshii sp. nov. Jap. Himechasenshida, ヒヌチャをンレダ YaMato: Mt. Yamato (K. Mori).

Asplenium Toramana sp. nov. Jap. Kuroganeshida. クロガチシダ TosA (S. Tsuki, Torama Yoshinaga).

Asplenium shikokianum sp. nov. Aspl. Wrightii Eat. var., Bot. Mag., Tōkyō Bot. Soc. vol. III, no. 24, p. 69. Aspl. bulbiferum Forst. var., 1. c. vol IV, no. 46, p. 453. Jap. Hayamashida. メ $\bullet シ タ$ Tosa: 